\title{
Description of the larva of Orthemis schmidti (Odonata, Libellulidae)
}

\author{
Janira M. Costa \& Tatiana C. Santos
}

Departamento de Entomologia, Museu Nacional, Universidade Federal do Rio de Janeiro, Quinta da Boa Vista, São Cristovão, 20940-040 Rio de Janeiro, RJ, Brazil. (jcosta@globo.com)

\begin{abstract}
The larva of Orthemis schmidti Buchholz, 1950 is described and illustrated for the first time based on one specimen from the northeastern region Brazil. Diagnostic characters which separate this larva from known larvae of other congeners are mentioned, and some notes on the habitat of the species are presented.
\end{abstract}

KEYWORDS. Brazil, Maranhão, Anisoptera, imature form.

RESUMO. Descrição da larva de Orthemis schmidti (Odonata, Libellulidae). A larva de Orthemis schmidti Buchholz, 1950 é descrita e ilustrada pela primeira vez, com base em um espécime do Nordeste do Brasil. Caracteres diferenciais que separam esta larva de outras espécies do gênero são citados e algumas notas sobre o hábitat da espécie são apresentadas.

PALAVRAS-CHAVE. Brasil, Maranhão, Anisoptera, forma imatura.

Orthemis Hagen, 1861 includes 18 described species, 15 of which occur in Brazil. Larvae of five species have been described: Orthemis aequilibris Calvert, 1909 and $O$. biolleyi Calvert, 1906 by FLECK (2003), O. ferruginea (Fabricius, 1775) by NEEDHAM (1904), O. levis Calvert, 1906 by De Marmels (1990) and O. nodiplaga Karsch, 1891 by RodRIGUes-CAPítulo \& MuZón (1990).

The larva of Orthemis can be characterized as follows: coloration brown to dark-brown, body ovoid and hairy, head quadrangular, eyes small and protuberant, abdomen without dorsal hooks and lateral spines present on segments 8-9.

\section{MATERIAL AND METHODS}

Adults of $O$. schmidti Buchholz, 1950 and $O$. discolor Burmeister 1839, were found at a small stream close to the Parnaíba river near Timon city, Maranhão. The larvae collected were reared until emergence. Species determination was based on the teneral imago, which conforms to the characters mentioned by BuchHOLz (1950).

The original descriptions of the larvae of following species were used for comparison: $O$. aequilibris, $O$. biolleyi, $O$. ferruginea, $O$. levis and $O$. nodiplaga.

Exuviae were stored in $75 \%$ ethyl alcohol and illustrated using a stereo microscope and camera lucida. Mandibular formula is based of WATSON (1956). All material examined is deposited in the Museu Nacional, Rio de Janeiro, Brazil (MNRJ).

\section{Orthemis schmidti Buchholz, 1950}

$$
\text { (Figs. 1-7) }
$$

Distribution. Peru, Surinam, French Guiana, Brazil (Amazonas, Amapá, Pará, Acre, and this is the first record from State of Maranhão).

General shape of body typical of Orthemis (Fig. 1), i.e., hairy, similar to larva of $O$. ferruginea and $O$. levis, in dorsal view. General color light brown.
Head (Fig. 1). Quadrangular, as broad as thorax in dorsal view; occipital region almost straight; eyes small and protruding in dorsal view and long in frontal view; antennae 7 -segmented (Fig. 2), $3^{\text {th }}$ antennomere the longest, $1^{\text {st }}$ the shortest, $2^{\text {nd }}$ and $4^{\text {th }}$ subequal in size, $5^{\text {th }}$ and $6^{\text {th }}$ also subequal, each bearing small spiniform setae. Mandibles (Figs. 3, 4) with 4 incisor teeth; left mandibles with two molar teeth and right mandibles with three; mandibular formula: L $123+4$ a d / R $123+4$ a b d. Labium short and wide, reaching anterior margin of second coxae; prementum (Fig. 5) with 3-5 long setae followed by 8-9 short setae; four spines on junction of labial palps. Distal margin of mentum crenulated with a large central tooth and four small setae under the tooth. Labial palp (Fig. 6) triangular with 8 setae; movable hook small; distal margin of palp with 9 crenulations, each bearing 1-4 spiniform setae; internal margin with 12 short spiniform setae; external margin bare.

Thorax. Similar to O. levis, O. ferruginea and $O$. nodiplaga, i.e., general shape of pronotum slightly quadrate. Wing pads divergent, reaching distal margin of abdominal segment 4. Legs short and with long hairs; posterior femora reaching to distal end of abdominal segment 4.

Abdomen. Ovoid, with lateral spines on segments 8 and 9 (Fig. 1), widest at segment 4. Middorsal hooks absent. Lateral spines on segments 8 and 9 nearly equal in length and equaling about $1 / 4$ the length of their respective segments. Anal appendages with long hairs and setae, conical (Fig. 7), acuminate; epiproct straight reaching to nearly the tip of the paraproct; cercus short, extending to half-length of epiproct.

Measurements (in mm): Total length 22; hind femur 6; hind tibia 6.2; epiproct 2.5; cerci 1; paraprocts 2.6.

Material. BRAZIL, Maranhão: Timon, Sítio Boa Vista (0801'00" S; 3456'00" W), 19-20.VIII.2004, 5 larvae (40", 1 ) and 1 exuviae $\left({ }^{7}\right)$, J.M.Costa \& C.M.P. Martins leg. (MNRJ). 


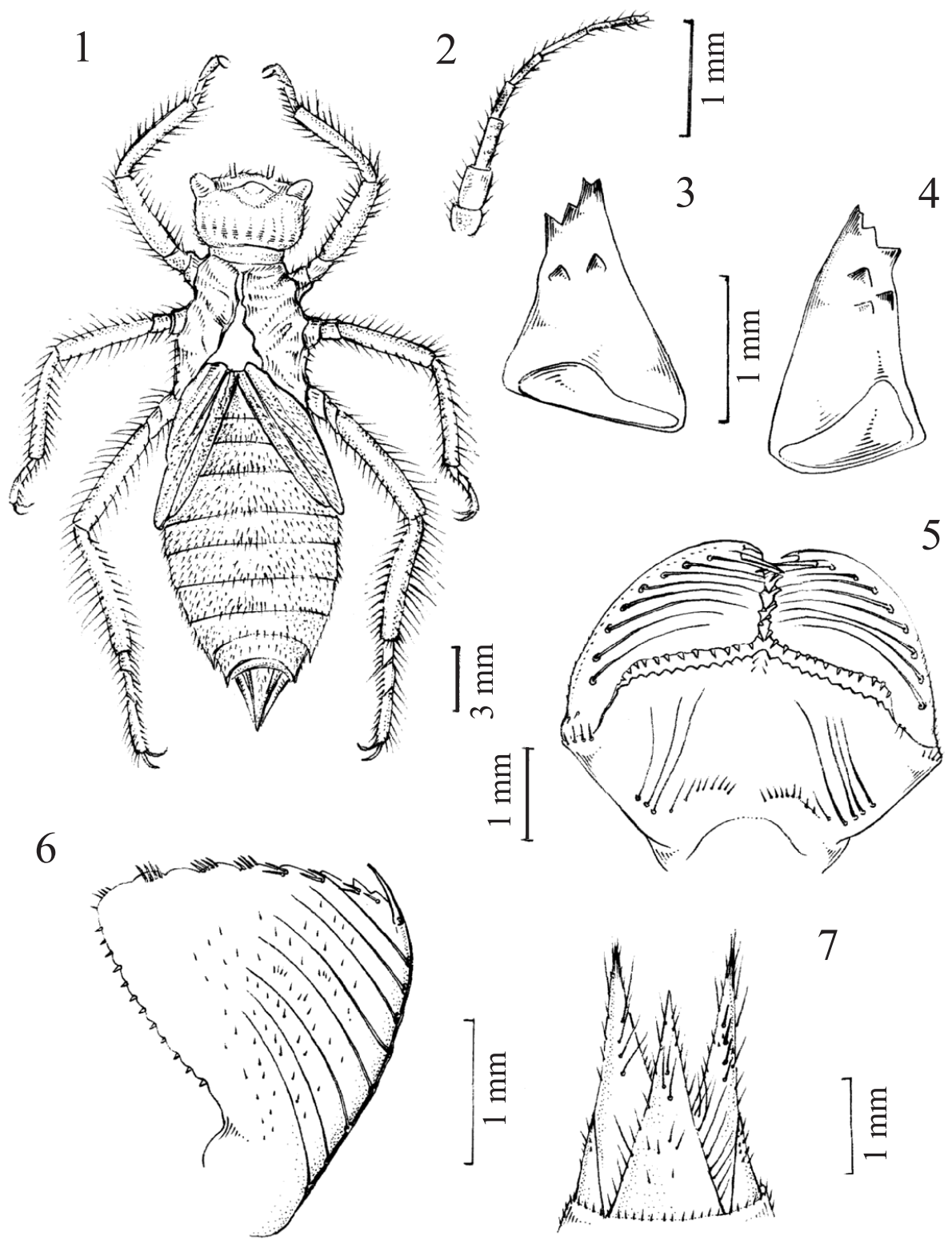

Figures. 1-7. Orthemis schmidti Buchholz, 1950 larva ${ }^{7}$. 1, larva in dorsal view; 2, antennae; 3, left mandible; 4, right mandible; 5, labium; 6 , right labial palp; 7 , anal appendages.

Biology. Larvae were collected in a small temporary muddy-bottomed puddle measuring about $1.5 \mathrm{~m}$ in length by $1 \mathrm{~m}$ in width and $0.20 \mathrm{~m}$ in depth.

Other Odonata larvae found were Erythrodiplax fusca (Rambur, 1842) and Pantala flavescens (Fabricius, 1798). The adult of $O$. schmidti and following species were captured at this site during our work: E. fusca, E. basalis (Kirby, 1897), P. flavescens, Miathyria marcella (Selys in Sagra, 1857), O. discolor, Perithemis lais (Perty, 1834) and Erythemis plebeja (Burmeister, 1839).

\section{DISCUSSION}

The larva of $O$. schmidti is similar to $O$. ferruginea described by NeEDHAM (1904) and O. levis described by De Marmels (1990) from which it differs by the number of palpal setae: 6 in O. levis, 8-9 in O. ferruginea and $O$. schmidti; and by absence of y-tooth in O. schmidti (present in $O$. ferruginea). Can be distinguished from that of $O$. aequilibris, $O$. biolleyi and $O$. nodiplaga by following characters: 1) palpal setae 11 in O. aequilibris, 7 in O. biolleyi, 7-8 in O. nodiplaga (8 in O. schmidti); 2 ) mental setae 12-13 in O. aequilibris, 14-15 in O. biolley, 12 in $O$. nodiplaga (11-14 in $O$. schmidti); 3 ) epiproct curved down in $O$. aequilibris and $O$. biolleyi (straight in $O$. schmidti and $O$. nodiplaga).

The larva described by NeEDHAm (1904), probably, is $O$. ferruginea. We compared the original description with 10 exuviae of $O$. discolor emerged in laboratory, from Rio de Janeiro (Ilha da Marambaia).

The larva described by CALvert (1928) as $O$. ferruginea is the true $O$. discolor, by the characters following: 1) labial palps with 9 crenulations on the distal margin $(8$ in $O$. ferruginea $) ; 2$ ) labial palps with 9 setae $(8$ in $O$. ferruginea); 3) prementum with 11-16 setae, 13 most frequent (10 in O.ferruginea); 4) 2-3 setae of each labial 
crenulations (3-4 in O. ferruginea). In our specimens of O. discolor and that described by CALVERT (1928) the epiproct is curved down, not described in $O$. ferruginea by NEEDHAM (1904).

Acknowledgments. This research was supported by the Conselho Nacional de Desenvolvimento Cientítfico e Tecnológico (CNPq). We would like to thank L. A. Alves Costa for the drawings that illustrate this article.

\section{REFERENCES}

Buchнolz, K. 1950. Zwei neue Orthemis-arten (Odonata, Libellulidae). Bonner Zoologische Beiträge 1:79-82.

Calvert, P. P. 1928. Report on Odonata, including notes on some internal organs of the larvae. Collected by the Barbados
- Antigua Expedition from the University. Iowa Studies in Natural History 12(2):1-44.

De Marmels, J. 1990. Nine new Anisoptera larvae from Venezuela (Gomphidae, Aeshnidae, Corduliidae, Libellulidae). Odonatologica 19(1):1-15.

FLECK, G. 2003. Contribution à la connaissance des odonates de Guyane Française: notes sur des larves des genres Orthemis, Diastatops et Elga (Anisoptera: Libellulidae). Odonatologica 32(4):335-344.

NeEdham, J. G. 1904. New dragonflies nymphs in United States National Museum. Proceedings of the United States National Museum 27:685-720.

Rodrigues-Capitulo, A. \& Muzón, J. 1990. The larval instar of Orthemis nodiplaga Karsch, 1891 from Argentina (Anisoptera: Libellulidae). Odonatologica 19(3):283-291.

WATSON, M. C. 1956. The utilization of mandibular armature in taxonomic studies of anisopterous nymphs. Transactions of Americam Entomological Society 81:155-209.

Recebido em outubro de 2007. Aceito em setembro de 2008. ISSN 0073-4721

Artigo disponível em: www.scielo.br/isz 